\title{
Comparison between Couple Attachment Styles, Stress Coping Styles and Self-esteem Levels
}

\author{
Oğuzhan Çolakkadioğlư ${ }^{1, *}$, Turan Akbaş ${ }^{2}$, Sevcan Karabulut Uslu ${ }^{3}$ \\ ${ }^{1}$ Department of Psychological and Guidance, Mustafa Kemal University, Turkey \\ ${ }^{2}$ Department of Psychological and Guidance, Çukurova University, Turkey \\ ${ }^{3}$ Psychological Counselor, Turkey
}

Copyright $\odot 2017$ by authors, all rights reserved. Authors agree that this article remains permanently open access under the terms of the Creative Commons Attribution License 4.0 International License

\begin{abstract}
Data were acquired from a total of 422 university students with 216 female and 206 male students via Couple Attachment Scale, Stress Coping Styles Scale and Coopersmith Self-Esteem Inventory. Positive and statistically significant relationships were determined between self-confident approach, optimistic approach and social support approach sub-scales as a result of Pearson Product Moments Correlation Coefficient analysis; whereas a negative and statistically significant relationship was determined between helpless approach and submissive approach sub-scales and self-esteem. It was determined as a result of the One Way MANOVA analysis that couples with secure and insecure attachment differ with regard to ways of coping with stress and self-esteem levels and that couples with secure attachment make use of self-confident approach, optimistic approach and social support approach from among styles of coping with stress, whereas couples with insecure attachment use helpless approach and submissive approach styles and that they have lower self-esteem levels.
\end{abstract}

Keywords Attachment Styles, Attachment in Couples, Coping with Stress and Self-esteem

\section{Introduction}

Attachment and separation are concepts that we face throughout our lives. Whether we end up as adults who are able to attach or not depend mostly on our childhood experiences with our mother (Fonagy, 1995; Jellema, 1999). Our subconscious is home to fears about our relations. It is thus related with whether our brain connects the concept of attachment with "safety, warmness and protection" or with "abandonment, loneliness and fear".

Babies are born with needs and emotions. The world of emotions consists solely of happiness and unhappiness. Unhappiness may arise due to hunger, thirst, cold and hot or bodily complaints. Babies cannot cope with unhappiness, they start crying and shouting when faced with a strong stress. The mother is responsible from reducing the stress of the baby and calming it as well as feeding and warming it. In addition to removal of its unhappiness, the baby also needs social relations and human attention from birth (Schneider, 1991). So, the mother is responsible not only from calming and relaxing the baby but also making it part of the happiness due to the interest and dialogue among people.

Over time, the baby starts managing its own interests and needs thus giving clearer signals. The mother starts perceiving these signals better. The child knows that his/her mother perceives him/her and also learns his/her own effect in the satisfaction of his/her needs. The child wants to move around and get to know his/her environment out of not only attracting attention but also out of a desire for freedom. It is important at this point that the mother is able to leave him/her alone. The child realizes that he/she can trust his/her mother since the mother is there when he/she needs her and that she leaves him/her alone whenever he/she wants to be left alone. The mother becomes the source of trust and consolation. Thanks to the emotional behaviors of the mother, the child learns to trust personal relations; that is he/she learns fundamental trust. This is also the sense of trust, favorable reception and acceptance (Stahl, 2014).

There is a bridge between the attachment behavior that develops during the first two years of infancy and the attachment behaviors observed in childhood and adulthood (Schneider, 1991). Even though the organization of attachment behavior changes with advancing age, it has the same goals with infancy attachment behavior at its core (Hamilton,2000). Even though attachment develops during infancy and early childhood years, it has positive or negative impact on the later years of life and plays a fundamental role in the development of social relations throughout life (Crowell \& Treboux, 1995; Fairchild, 2009; George \& West, 1999; Lapsey, Varshney, \& Aalsma, 
2000).

Studies carried out on examining the relations between coping styles and couple relations (Collins \& Read, 1990; Feeney \& Noller, 1990; Hazan \& Shaver, 1990; Simpson, 1990) put forth that individuals with secure attachment invest more in the relationship in comparison with individuals who are both anxious and have avoidant attachment style, that they live more agreeable and satisfactory relationships, that they have greater partner acceptance, experience more freedom and find more active and constructive methods for coping with stress. In other words, romantic partner relations are directly related with attachment since they are strong and long lasting relations that include mutual commitment and strong emotions. Many studies carried out (Banse, 2004; Cook, 2000; Feeney, 1999/2003; Feeney \& Hahous, 2001) indicate that attachment that develops during childhood affects the quality of adult relations in later years.

Bowlby (1980) puts forth that children internalize their relations depending on their relations with the figures of attachment. Individuals with healthy attachment are more independent, curious, enterprising and brave. Studies have put forth that $72 \%$ of securely attached individuals have high self-esteem (Cobb, 2001). Self-esteem in this study is a variable that is handled in relation with the attachment styles of couples. Self-esteem is an individual's perception of himself/herself in all his/her positive and negative sides, that is how he/she sees himself/herself (Rosenberg, 1979). Self-competence and positive self-evaluation of individuals depend on whether they establish secure relations with their environment or not. Children learn humane emotions, instincts, cooperation, resolving conflicts, understanding themselves and the reactions they will give during the difficult periods of life by way of individuals they are attached to. Secure attachment enables healthy emotional and social development and may make the individual more resistant against conditions of stress. The baby generalizes this emotion and directs it towards its social world as it has trust based experiences with its parents. The self-esteems of children who have not been able to earn a sufficient sense of trust in their first relations will be negatively affected since they will behave more suspicious and insecure to those around them (Roberts, Gotlip, \& Kassel, 1996) and the individual will revert to negative coping strategies when faced with stress (Mikulincer \& Florian, 1995).

Coping with stress which is taken into consideration as another variable related with the coping styles of couples (Mikulincer, 1998) is learning to keep the effect of stress at a positive level. Stress is the emotional or physical response of an individual at all ages as "I am having a difficult time" against a certain event or state with adverse effects on the harmony of the individual with his/her environment (Baltaş \& Baltaş, 2000; Folkman, Lazarus, Gruen, \& Delongis, 1986; Lazarus \& Folkman, 1984). Factors that result in stress are different for each individual and their responses to stress are also specific (Lazarus,
1993). Styles of responding to stress are affected from many factors. Upbringing, self-conception, self-confidence, individual's perception of one's own self and the environment along with how the individual directs himself/herself in his/her behavior and thoughts affect the response of the individual against stress. The perception and thought of the individual regarding the level at which he/she controls his/her own life play an important role in the response when faced with stress. The communication of the individual with his/her environment along with whether stress is perceived physically or emotionally affects the response against stress (Tutar, 2011).

In short, the internal models generated by the individual during the first years of his/her life function throughout his/her life (Collins \& Read, 1990). These structures that are fundamental for determining attachment styles are also sources of emotions, thoughts and behaviors in the close relations during adulthood (Bowlby, 1982; Hazan \& Shaver, 1987). Self-esteem which is the judgment that the individual will reach as a result of an evaluation of his/her own positive and negative sides is also affected from this and may act either as a support or an obstacle for the individual in coping with life events. Hence, these three variables have been taken into consideration together in this study. The objective of this study within this scope was to compare the styles of coping with stress of couples and their levels of self-esteem. Answers were sought for the following questions within the scope of this general objective:

1. Are there statistically significant relationships between styles of coping with stress and self-esteem?

2. Do the styles of coping with stress of couples differ at a statistically significant level according to their attachment styles?

3. Do the self-esteem levels of couples differ at a statistically significant level according to their attachment styles?

\section{Method}

\section{Method of the Research}

This is a descriptive study with a relational screening model carried out for examining whether there are differences between the attachment styles of couples and their coping with stress and self-esteem levels. The dependent variables of the study were styles of coping with stress and self-esteem, whereas the independent variable was styles of attachment.

\section{Population-sampling}

The study group was comprised of married, engaged or dating couples who have had a romantic partner for at least one month. The sample group of the study was comprised 
of students with partners who are continuing their education at the Faculties of Mustafa Kemal University or those who have graduated and are taking pedagogic formation education along with students with partners who are continuing their education at the Faculties of Çukurova University. Purposeful sampling from among random sampling methods was used for determining the sample group of the study. Many purposeful sampling methods have been defined in literature and criteria sampling method was used in this study. This sampling method is based on studying all instances that meet a series of pre-determined criteria (Büyüköztürk, Çakmak, Akgün, Karadeniz, \& Demirel, 2008). The criteria determined for the study was for the individual to have a romantic relationship that has been ongoing at least for one month.

\section{Data Collection Tools}

Couple Attachment Scale (CAS) has been developed by Grau (1999) for measuring the two dimensions (anxious and avoidant) of insecure attachment. The scale is comprised of two sub-scales. Whereas anxious sub-scale takes into consideration anxieties such as being abandoned by the partner or being unloved and not receiving attention, Avoidance sub-scale measures staying away from emotional closeness in a couple relationship as well as the anxiety of being controlled and smothered by the partner. Items are responded with scores of between 1 (Not at all characteristic of me) and 7 (Very characteristic of me). The highest score that can be obtained from the sub-scales is 70 , whereas the lowest score is 10 . The score results of the sub-scales indicate 4 different attachment styles of secure, anxious, avoidant and anxious-avoidant. Scores of 30 and below from each of the two sub-scales indicate secure attachment, scores of 31 and above from both sub-scales indicate anxious-avoidant attachment, scores of 31 and above from avoidant sub-scale and scores of 30 and below from anxious sub-scale indicate avoidant attachment, whereas scores of 31 and above from anxious sub-scale and scores of 30 and below from the avoidant sub-scale indicate anxious attachment. The Cronbach alfa coefficient of the anxious attachment sub-scale was determined as .91, whereas the Cronbach alfa coefficient of the avoidant attachment sub-scale was determined as .86 (Grau, 1999). Adaptation study for the Couple Attachment Scale was carried out by Çolakkadıoğlu, Akbaş and Yıldızeli (2016). DFA was applied for verifying the factors in the original form within the scope of the construct validity of CAS. It was observed as a result of the confirmatory factor analysis that as is the case for the original scale, CAS is in accordance in both sub-dimensions and that all items have been placed in the related sub-scale. Relationship Satisfaction Scale (RSS) was used for examining the criterion related validity of CAS. Negative and statistically significant relationships were determined between RSS scores and the CAS sub-scale scores. In addition, the
Cronbach alfa coefficient of CAS was determined as .85 for the anxiety sub-scale, as .88 for the avoidance sub-scale: whereas test-re-test consistency was determined as .80 for the anxiety sub-scale and as .83 for the avoidance sub-scale. Statistical analyses carried out for CAS have put forth that CAS is a valid and reliable scale which can be used for determining the attachment styles of couples (Çolakkadıoğlu, Akbaş, \& Yıldızeli, 2016). In this study, the anxious sub-scale internal consistency of the Couple Attachment Scale was determined as Alpha $=.65$, whereas the internal consistency coefficient of the avoidant sub-scale was determined as Alpha $=.70$.

Styles of Coping with Stress Scale (SOCWS) have been developed by Folkman and Lazarus (1980). The scale is comprised of 66 items and five sub-scales. These sub-scales are self-confident approach, helpless approach, optimistic approach, submissive approach and social support. The items are evaluated by marking one of the four categories. The Cronbach Alpha Reliability Coefficients of the scale adapted into Turkish by Şahin and Durak (1995) were determined in three different studies to vary between .68 and .49 for the optimistic approach sub-dimension, between .62 and .80 for the self-confident approach dimension, between .64 and .73 for the helpless approach sub-dimension, between .47 and .72 for the submissive approach sub-dimension and between .47 and .45 for the social support sub-dimension. The internal consistency coefficient for the optimistic sub-dimension of Styles of Coping with Stress Scale was determined in this study as Alpha $=.68$, internal consistency coefficient for the self-confident approach sub-scale was determined as Alpha $=.71$, the internal consistency coefficient for the helpless approach sub-scale was determined as Alpha $=.64$, the internal consistency coefficient for the submissive approach sub-scale was determined as Alpha $=.67$ and the internal consistency coefficient for the social support sub-scale was determined as Alpha $=.72$.

Coopersmith Self-Esteem Inventory (CSEI) has been developed in 1967 by Stanley Coopersmith for determining the self-esteem level of individuals. This inventory that was first prepared with 50 items for children was then developed further to be applied to individuals in different age groups. It has two different forms for children and adults. There are 25 items with discotomic response choices in the adult form for measuring self-esteem such as "like me" or "unlike me". The scale was translated into Turkish first by Onur (1981). It was later used on 30 cancer patients by Turan and Tufan (1987). This inventory was applied on cancer patients within an interval of two weeks and the test-re-test reliability coefficient was determined as $r=0.65$. Test-re-test reliability coefficient of the inventory was determined as $r=0.76$ as a result of its application on a university student sample group comprised of 56 people within an interval of two weeks. The internal consistency coefficient of the Coopersmith Self-Esteem Inventory was determined as Alpha $=.74$ in this study. 


\section{Analysis Techniques}

Scores obtained from all scales used in the study (CAS, SBTÖ, BSÖ) along with personal information were uploaded to the SPSS 22.0-Statistics Package Software for Social Sciences for each individual. Scores obtained from Couple Attachment Scale and Styles of Coping with Stress Scale sub-dimensions were calculated separately. The data were then classified according to attachment styles after which data analysis was carried out. Pearson Correlation Coefficient technique was used in the first stage of the analyses for determining whether the relationship between the continuous variables (styles of coping with stress and self-esteem) was statistically significant or not. One way MANOVA was used in the second stage of the analyses. For this purpose, it was tested whether the assumptions related with One Way MANOVA were met or not (Pallant, 2005). It was first determined that the acquired data meet the single and multi-variable normality condition, that there are no outliers, that there is a linear relationship between the dependent variables and that there is no problem of multicollinearity. However, it was determined that the variance-covariance matrices do not meet the homogeneity condition. Since this is affected significantly from the magnitude of the number of participants in the study (Tabachnick \& Fidel, 2007), Pillai'sTrace result was taken into consideration instead of Wilk's Lambda value to continue the analyses.

\section{Findings}

Findings related with the correlation method used for determining the relationship between the variables was first included in the presentation of results. Following the results for the relations, arithmetic average, standard deviation and frequency values were then presented for the dependent variables according to the attachment styles variable for each sub-problem after which one way variance analysis results were provided. Findings related with the multivariate ANOVE (MANOVA) test used for determining whether the attachment style variable has a statistically significant effect on the dependent variables or not were included in the final section of the results.

Are there statistically significant relationships between the styles of coping with stress of couples and their self-esteem levels?

The relationships between styles of coping with stress depending on the attachment style of couples and their self-esteem levels were examined with results given in Table 1.

Table 1. Correlation Table for the Relationships between the Styles of Coping with Stress of Couples and Their Self-esteem Levels

\begin{tabular}{|c|c|c|c|c|c|c|c|}
\hline & Variable & Self-esteem & Self-confident & Helpless & Submissive & Optimistic & Social support \\
\hline 1 & Self-esteem & 1 & $.488 * *$ & $-.602 * *$ & $-.514 * *$ & $.275^{* *}$ & $.177 * *$ \\
\hline 2 & Self-confident approach & & 1 & $-.390 * *$ & $-.378 * *$ & $.232 * *$ & $.266^{* *}$ \\
\hline 3 & Helpless approach & & & 1 & $.436 * *$ & $-.171 * *$ & $-.106^{* *}$ \\
\hline 4 & Submissive approach & & & & 1 & $-.148^{* *}$ & $-.109 * *$ \\
\hline 5 & Optimistic approach & & & & & 1 & $.171^{* *}$ \\
\hline 6 & Social support & & & & & & 1 \\
\hline
\end{tabular}

$* * \mathrm{p}<.01, * \mathrm{p}<.05$

Whereas according to the Pearson Correlation Coefficient results, self-esteem puts forth positive and statistically significant relationships with sub-scales of styles of coping with stress which are self-confident approach $(\mathrm{r}=.488 ; \mathrm{p}<.01)$, optimistic approach $(\mathrm{r}=.275 ; \mathrm{p}<.01)$ and social support $(\mathrm{r}=.177 ; \mathrm{p}<.01)$, it had negative and statistically significant relationships with helpless approach $(\mathrm{r}=-.514 ; \mathrm{p}<.01)$ and submissive approach $(\mathrm{r}=-.390 ; \mathrm{p}<.01)$. Descriptive values for styles of coping with stress and self-esteem levels of couples according to their attachment styles have been given in Table 2. 
Table 2. Descriptive Values for Styles of Coping with Stress and Self-esteem Levels According to their Attachment Styles

\begin{tabular}{|c|c|c|c|c|}
\hline Scale/Sub-Scale & Attachment styles & $\mathrm{N}$ & $\overline{\mathrm{X}}$ & SS \\
\hline \multirow{5}{*}{ Self-confident approach } & Secure & 109 & 14.35 & 3.88 \\
\hline & Anxious & 107 & 7.77 & 3.17 \\
\hline & Avoidant & 102 & 8.53 & 3.52 \\
\hline & Anxious-avoidant & 104 & 7.75 & 3.28 \\
\hline & Total & 422 & 9.65 & 4.45 \\
\hline \multirow{5}{*}{ Helpless approach } & Secure & 109 & 7.44 & 3.82 \\
\hline & Anxious & 107 & 16.84 & 3.12 \\
\hline & Avoidant & 102 & 14.86 & 4.19 \\
\hline & Anxious-avoidant & 104 & 15.96 & 3.88 \\
\hline & Total & 422 & 13.71 & 5.32 \\
\hline \multirow{5}{*}{ Submissive approach } & Secure & 109 & 6.40 & 3.08 \\
\hline & Anxious & 107 & 11.15 & 2.80 \\
\hline & Avoidant & 102 & 12.70 & 3.04 \\
\hline & Anxious-avoidant & 104 & 12.07 & 3.14 \\
\hline & Total & 422 & 10.53 & 3.91 \\
\hline \multirow{5}{*}{ Optimistic approach } & Secure & 109 & 10.12 & 2.68 \\
\hline & Anxious & 107 & 7.81 & 2.78 \\
\hline & Avoidant & 102 & 7.34 & 2.49 \\
\hline & Anxious-avoidant & 104 & 8.11 & 2.78 \\
\hline & Total & 422 & 8.37 & 2.74 \\
\hline \multirow{5}{*}{ Social support } & Secure & 109 & 7.72 & 2.68 \\
\hline & Anxious & 107 & 6.22 & 2.78 \\
\hline & Avoidant & 102 & 6.46 & 2.49 \\
\hline & Anxious-avoidant & 104 & 6.64 & 2.78 \\
\hline & Total & 422 & 6.77 & 2.74 \\
\hline \multirow{5}{*}{ Self-esteem } & Secure & 109 & 80.84 & 10.80 \\
\hline & Anxious & 107 & 40.05 & 10.58 \\
\hline & Avoidant & 102 & 39.33 & 9.42 \\
\hline & Anxious-avoidant & 104 & 40.73 & 11.28 \\
\hline & Total & 422 & 50.58 & 20.74 \\
\hline
\end{tabular}

As can be seen in Table 2, styles of coping with stress score averages and self-esteem score averages of couples with different attachment styles differ according to styles of attachment. One Way MANOVA was applied to test whether these observed differences are statistically significant or not and the results have been given in Table 3 .

Table 3. One Way MANOVA Analysis Results Table for Styles of Attachment Variable

\begin{tabular}{cccccc}
\hline Effect & Pillai' Trace & F & $\begin{array}{c}\text { Hypothesis Degree of } \\
\text { Freedom }\end{array}$ & $\begin{array}{c}\text { Error Degree of } \\
\text { Freedom }\end{array}$ & $\begin{array}{c}\text { Level of } \\
\text { Significance }\end{array}$ \\
\hline $\begin{array}{c}\text { Attachment } \\
\text { Styles }\end{array}$ & .943 & 31.715 & 18.000 & 1245.000 & .000 \\
\hline
\end{tabular}

As can be seen in Table 3, the "Pillai $\Lambda=.943 ; \mathrm{F} 18-1245=31.75, \mathrm{p}=.000$ " value obtained as a result of the One Way MANOVA indicates that there is a statistically significant difference between the styles of coping with stress sub-scale scores and self-esteem scores of couples according to their attachment styles. In other words, styles of attachment cause differences on styles of coping with stress and self-esteem. Multivariate ANOVE Test was applied for determining the source of this difference and the results have been given in Table 4. 
Table 4. Multivariate ANOVA Results Table for the Styles of Attachment Variable

\begin{tabular}{|c|c|c|c|c|c|c|c|c|}
\hline Dependent Variable & Group & $\mathrm{N}$ & $\overline{\mathrm{X}}$ & $\mathrm{S}$ & sd & $\mathrm{F}$ & $\mathrm{P}$ & $\eta 2$ \\
\hline \multirow{4}{*}{$\begin{array}{l}\text { Self-confident } \\
\text { approach }\end{array}$} & Secure & 109 & 14.35 & 3.88 & \multirow{4}{*}{$3-418$} & \multirow{4}{*}{90.488} & \multirow{4}{*}{0.000} & \multirow{4}{*}{0.394} \\
\hline & Anxious & 107 & 7.77 & 3.17 & & & & \\
\hline & Avoidant & 102 & 8.53 & 3.52 & & & & \\
\hline & Anxious-Avoidant & 104 & 7.75 & 3.28 & & & & \\
\hline \multirow{4}{*}{ Helpless approach } & Secure & 109 & 7.44 & 3.82 & \multirow{4}{*}{$3-418$} & \multirow{4}{*}{140.393} & \multirow{4}{*}{0.000} & \multirow{4}{*}{0.502} \\
\hline & Anxious & 107 & 16.84 & 3.12 & & & & \\
\hline & Avoidant & 102 & 14.86 & 4.19 & & & & \\
\hline & Anxious-Avoidant & 104 & 15.96 & 3.88 & & & & \\
\hline \multirow{4}{*}{$\begin{array}{l}\text { Submissive } \\
\text { approach }\end{array}$} & Secure & 109 & 6.40 & 3.08 & \multirow{4}{*}{$3-418$} & \multirow{4}{*}{95.901} & \multirow{4}{*}{0.000} & \multirow{4}{*}{0.408} \\
\hline & Anxious & 107 & 11.15 & 2.80 & & & & \\
\hline & Avoidant & 102 & 12.70 & 3.04 & & & & \\
\hline & Anxious-Avoidant & 104 & 12.07 & 3.14 & & & & \\
\hline \multirow{4}{*}{ Optimistic approach } & Secure & 109 & 10.12 & 2.68 & \multirow{4}{*}{$3-418$} & \multirow{4}{*}{15.029} & \multirow{4}{*}{0.000} & \multirow{4}{*}{0.097} \\
\hline & Anxious & 107 & 7.81 & 2.78 & & & & \\
\hline & Avoidant & 102 & 7.34 & 2.49 & & & & \\
\hline & Anxious-Avoidant & 104 & 8.11 & 2.78 & & & & \\
\hline \multirow{4}{*}{$\begin{array}{l}\text { Social support } \\
\text { approach }\end{array}$} & Secure & 109 & 7.72 & 2.68 & \multirow{4}{*}{$3-418$} & \multirow{4}{*}{6.559} & \multirow{4}{*}{0.000} & \multirow{4}{*}{0.045} \\
\hline & Anxious & 107 & 6.22 & 2.78 & & & & \\
\hline & Avoidant & 102 & 6.46 & 2.49 & & & & \\
\hline & Anxious-Avoidant & 104 & 6.64 & 2.78 & & & & \\
\hline \multirow{4}{*}{ Self-Esteem } & Secure & 109 & 80.84 & 10.80 & \multirow{4}{*}{$3-418$} & \multirow{4}{*}{402.945} & \multirow{4}{*}{0.000} & \multirow{4}{*}{0.743} \\
\hline & Anxious & 107 & 40.05 & 10.58 & & & & \\
\hline & Avoidant & 102 & 39.33 & 9.42 & & & & \\
\hline & Anxious-Avoidant & 104 & 40.73 & 11.28 & & & & \\
\hline
\end{tabular}

It can be observed when Table 4 is examined that there are statistically significant differences between the self-confident approach $(\mathrm{F} 3-422=90.488, \mathrm{p}<.001, \eta 2=.394)$, helpless approach $(\mathrm{F} 3-422=140.393, \mathrm{p}<.001, \eta 2=.502)$, submissive approach (F3-422=95.901, $\mathrm{p}<.001, \eta 2=.408)$, optimistic approach $(\mathrm{F} 3-422=15.029, \mathrm{p}<.001, \eta 2=.097)$, social support approach scores (F3-422 $=6.559, \mathrm{p}<.001, \eta 2=.045)$ from among the sub-scales of the styles of coping with stress scale and self-esteem (F3-422 $=402.945, \mathrm{p}<.001, \eta 2=.743)$ scores for couples with secure attachment, anxious attachment, avoidant attachment and anxious-avoidant attachment styles. Results regarding the relationships between the styles of coping with stress for couples according to styles of attachment and their self-esteem levels have been summarized in Table 5. 
Table 5. Relationship between Styles of Coping with Stress and Self-Esteem According to Styles of Attachment

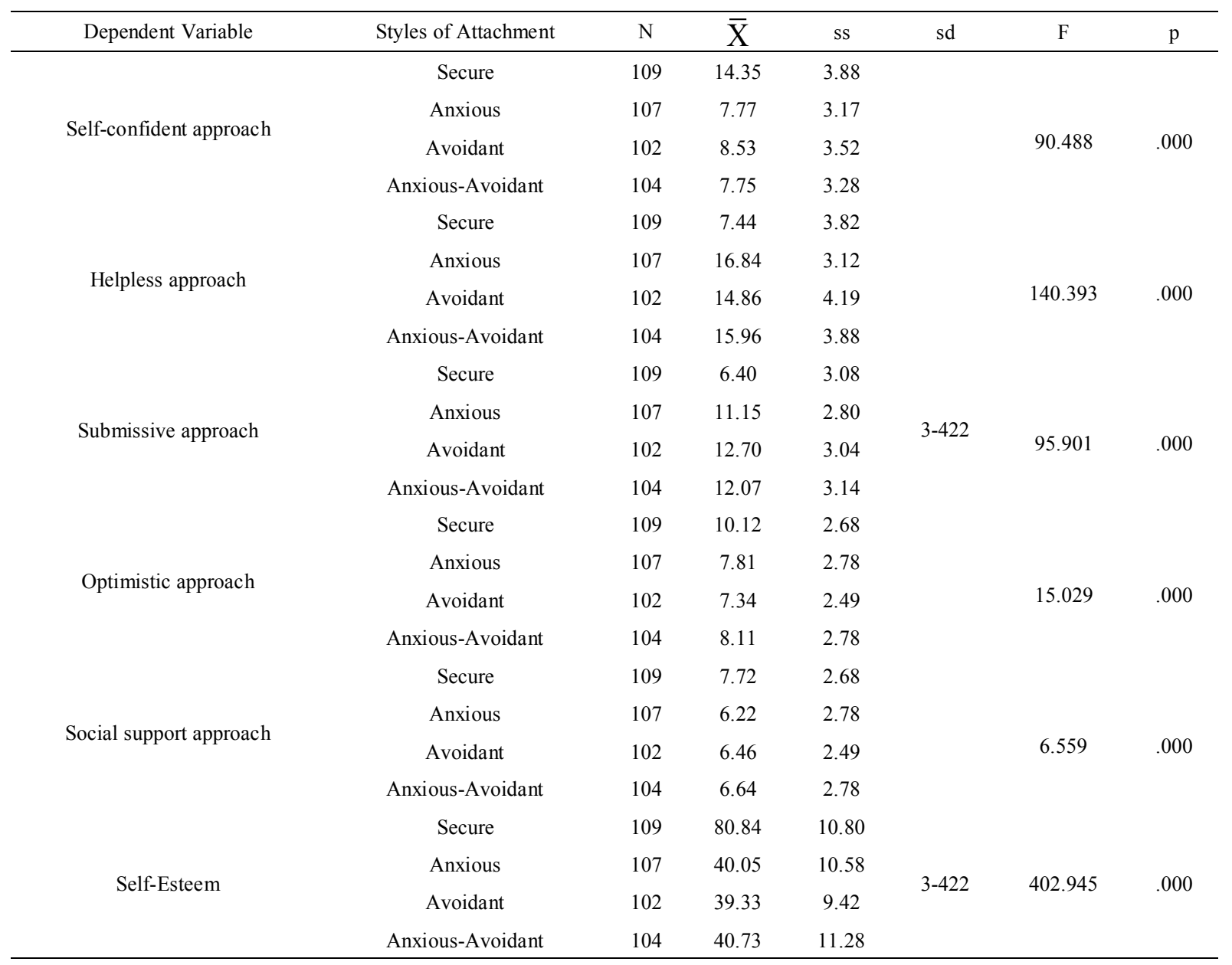

When the results given in Table 5 are examined, it can be observed that the optimistic coping sub-scale from the Styles of Coping with Stress of couples with secure attachment and when the scores obtained from the Self-esteem Scale were examined it can be observed that self-confident approach, optimistic approach, social support approach and self-esteem score averages are higher in comparison with other styles of attachment. It was determined that the negative coping sub-scale score averages from the Styles of Coping with Stress Scale for couples with anxious, avoidant and anxious-avoidant attachment are greater and that the self-esteem score averages are lower.

\section{Results, Conclusions and Recommendations}

Conclusion and Interpretation for the Findings Regarding the Relationship between Coping with Stress and Self-esteem

It was examined as a sub-problem during the study whether there is a statistically significant relationship between styles of coping with stress and self-esteem. The acquired results indicated that there is a positive and statistically significant relationship between self-esteem and self-confident approach, optimistic approach and social support approach from among the styles of coping with stress. It was also determined as a result of relationship analysis that there is a negative and statistically significant relationship between self-esteem and helpless approach and submissive approach.

Coping with stress is defined as cognitive and behavioral efforts developed by individuals themselves when faced with stressful situations or for overcoming the demands from their environment (Folkman \& Lazarus, 1988). Strategies for coping with stress are generally classified under two categories. These strategies that are known as problem focused and emotion focused may differ among individuals and situations. These strategies are expressed in almost all scales developed for measuring the styles of coping with stress (Endler \& Parker, 1990; Şahin \& Durak, 1995). The level of self-esteem is an important variable in determining the strategy used for coping with stress. Individuals with high self-esteem have high expectations regarding their own capacities. They believe in themselves because of their successes and trust in the results they 
acquire. The expectations and attitudes of individuals with high self-esteem direct them towards independence and creativity. High self-esteem provides positive mental attributes such as self-confidence, optimism, the desire to be successful and being undaunted by difficulties in addition to the belief in being valuable for others (Korkmaz, 1996). Hence, individuals with high self-esteem revert to problem-focused, active coping approaches (self-confident approach, optimistic approach) when faced with stress inducing factors in life. Individuals with low self-esteem easily give way to despair because their self-confidence levels are low and they tend to shift towards ineffective, emotion-focused strategies when faced with stress factors such as getting stuck in the problem, refraining from the problem and acceptance. Study results indicate that there is a statistically significant relationship between styles of coping with stress and self-esteem. There are many studies in literature with findings that are in parallel with these results (Hamarta, Arslan, Saygın, \& Özyeşil, 2009; Kurt, 2013; Üre, 2007; Yiğit, 2012).

Conclusion and Interpretation of the Relationship between Styles of Coping with Stress of Couples According to their Attachment Styles

It was examined in the study whether the styles of coping with stress of individuals with secure attachment and insecure attachment (anxious, avoidant, anxious-avoidant) differ or not and a statistically significant difference was observed. According to the results, couples with secure attachment style use self-confident approach, optimistic approach and social support approach more in comparison with couples with insecure attachment style (anxious, avoidant, anxious-avoidant). The acquired results indicate that individuals with insecure attachment style (anxious, avoidant, anxious-avoidant) revert more to helpless approach and submissive approach styles. This is in accordance with the opinions of Lopez and Brennan (2000) as well as the study results by Terzi and Cihangir-Çankaya (2009).

When the results were examined, it was observed that self-confident approach from among the positive coping mechanisms is used mostly by individuals with secure attachment style and least by individuals with anxious-avoidant attachment style. Whereas the group that used the optimistic approach the most was comprised of individuals with secure attachment, those who used it the least were individuals with avoidant attachment style. It was also determined that those who use the social support approach which is one of the most effective methods for coping with stress were those in the secure attachment style group; however, study results indicate that social support approach is also used as much by individuals with insecure attachment style (anxious, avoidant, anxious-avoidant). Individuals with secure attachment have high social support perceptions and that is why they tend to apply for social support frequently (Davis, Morris, \& Kraus, 1998; Kobak \& Sceery, 1988). Individuals with secure attachment patterns know that accepting and showing anxiety trigger reactions of support in other people and these people have experienced that asking for help from others, that is social support is effective when they are under threat.

It is understood that helpless approach from among mechanisms for coping with stress is used mostly by couples with anxious attachment and least by couples with secure attachment. Submissive approach which is another ineffective coping method is used least by couples with secure attachment, whereas it is used mostly by the group with an avoidant attachment style. This is in accordance with the opinions of Wei, Vogel, Ku and Zakalik (2005) as well as the study results by Belizaire and Fuertes (2011). Coping with stress is a complex process. Inividuals use most of the coping strategies when faced with stress. Lazarus (1993) put forth that reactions to stress kick in as a result of the mental interpretation of the stimulant. That is stress develops if the individual is of the opinion that the stimulant is dangerous. The reaction to stress of the individual along with the coping strategy to be used is shaped according to the characteristics of the individual and environmental properties. If the individual believes that he/she can do something he/she uses problem focused (self-confident approach, optimistic approach and social support approach) coping and emotion-focused coping if he/she believes that he/she cannot do something. The internal working models developed Bowlby are important in the process of evaluating the stress inducer as well as the coping strategies to be used. Since the means with which the first experiences of the individual developed along with the mental representations of the individual towards himself/herself as well as others affect his/her future life (Alanter \& Maner, 2008; Hamilton, 2000; Hazan \& Shaver, 1994; Schneider, 1991; Trinke \& Bartholomew, 1997;Zimmerman \& Becker- Stoll, 2002) it is inevitable that styles of coping with stress are affected from attachment styles. Caprara and Cervone (2000) state that the bond that develops between the baby and the primary care giver is passed down as a psychological heritage and that it is effective on the personality of the individual throughout his/her life.

According to the study results, individuals with secure attachment use effective and active coping methods when faced with stressful life events (Altundağ, 2011; Schottenbauer, Klimes-Dougan, Rodriguez, Amkoff, Glass, \& Lasalle, 2006; Wei, Heppner, \& Mallinckrodt, 2003) and shift towards applying to social support (Davis, Morris, \& Kraus, 1998; Kobak \& Sceery, 1988). These study results support the findings indicating that couples with secure attachment prefer problem focused or in other words effective coping methods (self-confident approach, optimistic approach and social support approach). It was put forth in the study carried out by Hamarta, Deniz, Durmuşoğu-Saltalı (2009) that individuals with secure 
attachment are more aware of their emotions, that they trust themselves more for overcoming problems, that they put forth a more adaptive behavior and that they have a higher motivation for coping with stress. Mikulincer and Florian (1995) put forth that secure attachment style is an internal source helping the individual in coping with stress. When the relevant literature is examined, it can be observed that individuals with secure attachment style tend to be better in controlling negative emotions that emerge when faced with stress (Mikulincer and Florian, 1995), that they trust themselves more in overcoming the negative emotions (McCarthy, Moller, \& Fouladi, 2001).

Insecure attachment develops (Anxious, avoidant and anxious-avoidant) when the distress that one experiences when faced with a dangerous event is coupled with the inaccessibility of the figure of attachment. Hall and Geher (2003) carried out a study in which it was put forth that individuals with insecure attachment may not cope with stress in a planned manner, they carry out unplanned actions when faced with stress, that they freeze up and that their movements slow down. There are also studies supporting the finding that individuals with insecure attachment styles use emotion-focused strategies when faced with stress. They tend to prefer being stuck in the problem, acting reactionally (Hayali-Emir, 2014; Janssen, Schuengel, \& Stolk, 2002; Lopez, Maurico, Gormley, Simko, \& Berger, 2001).

In cases when the attachment behavior is activated intensely, one needs to be alert with intensive effort until the figure of attachment is perceived and one feels secure. Excessively activating behavior is characterized with excessive anxiety. Exaggerations of the possibility of danger, negative perception of self, negative perception towards social relations, disaster scenarios are examples of this. Desire for support decreases when the individual is not allowed to reach the figure of attachment and the individual tries coping with his/her problems alone. The attachment system is immobilized in order to prevent the possibility of facing with problems in cases when the figure of attachment cannot be reached; thereby the individual refrains from problems that may arise when he/she is away from the figure of attachment. The individual denies his/her needs for attachment, refrains from close relations, keeps the distance with others at a maximum level and desires to be self-sufficient. Thus, attention is distanced from the stress inducing situation thanks to this tendency of distancing. Therefore, distressful memories and thoughts are suppressed. The individual first uses refraining strategies when faced with stress and only then reverts to strategies for suppressing and diverting in cases when they do not work. Individuals with avoidant attachment pattern immobilize stress related clues for coping with stress (Mikulincer, Shaver, \& Pereg, 2003). Ergin and Dağ (2013) put forth that avoidant attachment patterns are related with both unconfident and irresponsible approaches for solving interpersonal problems while also reporting that they have negative impact on effective problem solving behavior.

Individuals with anxious attachment style minimize their distance with the figure of attachment for coping with stress and try to maximize the safety that the figure of attachment may provide. Such individuals use strategies that will excessively activate attachment behavior and use behavioral patterns such as clinging and controlling. These people tend to emphasize the negative aspect of self-worth and may take actions that will excessively reflect the feeling of helplessness to others (Bowlby, 1998). The finding by Ergin and Dağ (2013) indicating that anxious attachment patterns are related with ineffective interpersonal problem solving behaviors is in parallel with our results. Studies in literature which indicate that individuals with secure attachment in romantic relations tend to cope with stress in a more constructive manner in comparison with individuals with insecure attachment (Amanvermez, 2007; Feeney \& Noller, 1990) also support our findings.

\section{Conclusion and Interpretation of Findings Related with the Comparison of the Self-Esteem Levels of Couples According to Their Styles of Attachment}

One of the sub-problems of the study was whether the self-esteem levels of couples who participated in the study differed according to attachment style or not. Findings related with this sub-problem indicate that the self-esteems of couples with secure attachment are higher at a statistically significant level. Terzi and Cihangir-Çankaya (2009) carried out a study in which they determined that secure attachment style is a significant precursor of self-esteem. In addition, the group with the lowest self-esteem score is the group with the avoidant attachment style. The self-esteem score averages of groups with anxious and anxious-avoidant attachment style are quite close to each other. Findings by Dağlıkan (2015) are similar with this result. This finding indicates that the self-esteem levels of couples with secure attachment are higher support the opinion of Bowlby (1980) that individuals with secure attachment style tend to evaluate themselves and their competencies positively. The relationship established with figures of attachment determines self-worth. Individuals with secure attachment tend to be more independent, curious, enterprising and brave. Studies indicate that $72 \%$ of those with secure attachment have high self-esteem (Cobb, 2001; Akt: Cebe, 2005).

Studies in literature indicating that individuals with secure attachment have a more positive sense of self (Alpay, 2009; Bylsma, Cozzarelli, \& Sümer, 1997; Celik, 2004; Damarl1, 2006; Hamarta, 2004; Huntsinger \& Luecken, 2004; Terzi \& Çankaya, 2009; Wilkinson \& Parry, 2004) and studies indicating the relationship between insecure attachment and low self-esteem 
(Bartholomew \& Horowitz, 1991; Collins \& Read, 1990; Muller, Lemieux, \& Sicoli, 2001) support the findings of our study.

It was observed as a result of the study by Hamarta (2004) examining the relationship between the attachment styles of university students and their close relations that the attachment styles of students explain their relational self-esteem scores at a statistically significant level. The relational self-esteem score averages of students in the secure attachment style group are higher in comparison with the score averages of students in the insecure attachment group at a statistically significant level.

Some researchers (Calhoun \& Acocella, 1990; Coopersmith, 1974; Kulaksızoğlu, 1998; Yavuzer, 1991; Yörükoğlu, 1978) are of the opinion that family is the most important factor for self-esteem development. The process that starts with the family accepting the child unconditionally will improve the self-esteem of the child. The position in life of the child that perceives himself/herself as valuable or invaluable will be shaped according to this perception. Family also has primary importance for the development of attachment. A secure bond will be formed if the child feels himself/herself valued, loved and protected in the family. Hence, the relationship between attachment styles and self-esteem is inevitable.

It was determined as a result of the study that the styles of coping with stress of couples and their self-esteem levels differ at statistically significant levels according to their attachment styles. It was concluded that couples with secure attachment style use problem focused, effective coping methods for coping with stress and that their self-esteem levels are higher, whereas couples with insecure attachment use emotion-focused, ineffective coping methods for coping with stress and that they have lower self-esteem levels. Couples were examined separately in this study comparing the styles of coping with stress and self-esteem levels of couples according to their styles of attachment. Studies examining the couples together may put forth better and more interesting data.

\section{REFERENCES}

[1] Alanter, Z., \& Maner, F. (2008). Eating disorders in the context of attachment theory. Anadolu Psikiyatri Dergisi, 9, 97-104.

[2] Altundağ, G. (2011). Examining attachment styles, coping styles with stress and perceived stress level among university students. Unpublished master's thesis. University of Haliç, İstanbul.

[3] Alpay, A. (2009). Forgiveness in close relationship: The investigation of forgiveness in terms of attachment, self-esteem, empathy and romantic jealousy. Unpublished master's thesis. University of Ankara, Ankara.
[4] Amanvermez, P. (2007). The relationships between attachment in close relationships and group attachment. Unpublished master's thesis. University of Hacettepe, Ankara.

[5] Avşaroğlu, S., \& Üre, Ö. (2007). The study of styles of coping with stress, decision-making and self-esteem of university students on decision-making in terms of self-esteem and some variables. Selçuk University Journal of Institute of Social Science, 18, 85-100.

[6] Baltaş, A., \& Baltaş, Z. (2000). Stress and ways of coping. İstanbul, Remzi Bookstore.

[7] Banse, R. (2004). Attachment style and marital satisfaction: Evidence for dyadic configuration effects. Journal of Social and Personal Relationships, 21, 273-282.

[8] Bartholomew, K., \& Horowitz, L. M. (1991). Attachment styles among young adults: A test of a four category model. Journal of Personality and Social Psychology, 61, 226-244.

[9] Belizaire, L. S., \& Fuertes, J. N. (2011). Attachment, coping, acculturative stress and quality of life among Haitian immigrants. Journal of Counseling \& Development, 89, 89-97.

[10] Bowlby, J. (1980). Attachment and loss: Sadness and depression. New York: Basic Books.

[11] Bowlby, J. (1982). Attachment and loss. New York: Basic Books.

[12] Bowlby, J. (1998). A secure base: clinical applications of attachment theory. London: Routledge.

[13] Büyüköztürk, Ş., Çakmak, E. K., Akgün, Ö. E., Karadeniz, S., \& Demirel, F. (2008). Scientific research methods. Ankara: Pegem Academy Publications.

[14] Bylsma, W. H., Cozzarelli, C., \& Sümer, N. (1997). Relation between adult attachment styles and global self-esteem. Basic and Applied Social Psychology, 19(1), $1-16$

[15] Calhoun, J. F., \& Acocella, J. R. (1990). Psychology of adjustment and human relationships. New York: Mc GrowHill Publishing Company.

[16] Caprara, G. V., \& Cervone, D. (2000). Interpersonal relations: Personality Determinants Dynamics and Potentials. United Kingdom, Cambridge University Press.

[17] Cebe, F. (2005). The depression anxiety and self-esteem scores of the children who live in social services and society for the protection of children's dormitories in comparison to the children who live with their family. Unpublished master's thesis. University of İstanbul, İstanbul.

[18] Cobb, N. J. (2001). The child infants and children. California: Mayfield Publishing Company.

[19] Collins, N. L., \& Read, S. J. (1990). Adult attachment, working models and relationship quality in dating couples. Journal of Personality and Social Psychology, 58 (4), 644-663.

[20] Cook, W. L. (2000). Understanding attachment security in family context. Journal of Personality and Social Psychology, 78, 285-294. 
[21] Coopersmith, S. (1974). The antecedents of self-esteem. San Francisco: WH. Freeman Company.

[22] Crowell, J. A., \& Treboux, D. (1995). A review of adult attachment measures: Implications for theory and research. Social Development, 4(3), 294-327.

[23] Çolakkadığlu, O., Akbaş, T. \& Yıldızeli, E. (2016). The adaptation study of attachment styles scale in couples to Turkish. In O. Titrek, L. Pavitola (Eds), $2^{\text {nd }}$ International Conference on Lifelong Education and Leadership for all Inside Abstract Book (pp 100). Ankara: Pegem Akademi.

[24] Dağlikan, S. (2015). Attachment styles and self-esteem of secondary school age children. Unpublished master's thesis. University of Beykent, İstanbul.

[25] Damarl1, Ö. (2006). Relationships between gender roles, attachment styles and self-concept among adolescents. Unpublished master's thesis. University of Ankara, Ankara.

[26] Davis, M. H., Morris, M. M., \& Kraus, L. A. (1998) Relationship specific and global perceptions of social support: Association with well-being and attachment. Journal of Personality and Social Psychology, 74(2), 468-481.

[27] Endler, N. S., \& Parker, J. D. A. (1990). Multidimensional assessment of coping: A critical evaluation. Journal of Personality and Social Psychology, 58(5), 844-854.

[28] Ergin, B. E., \& Dağ, İ. (2013). The relationships among interpersonal problem solving behaviors, adult attachment patterns, and psychological symptoms. Anatolian Journal of Psychiatry, 14, 36-45.

[29] Fairchild, S. R. (2009). Introduction to a special edition: Attachment theory and its application to practice. Child \& Adolescent Social Work Journal, 26, 287-289.

[30] Folkman, S., \& Lazarus, R. S. (1980). An analysis of coping in a middle-aged community sample. Journal of Health and Social Behavior, 21, 219-239.

[31] Feeney, J. A. (1999). Adult romantic attachment and couple relationships. Handbook of attachment: Theory, research and clinical applications. (Ed: Cassidy, J. \& Shaver, P.R.) New York: Guildford Press. 355-377

[32] Feeney, J. A. (2003). The systemic nature of couple relationships: An attachment perspective. In P. Erdman \& T. Caffery (Eds), Attachment and Family Systems. New York and Hove: Brunner Routledge.

[33] Feeney, J. A., \& Hohaus, L. (2001). Attachment and spousal caregiving. Personal Relationships, 8, 21-39.

[34] Feeney, J. A., \& Noller, P. (1990). Attachment styles as a predictor of adult romantic relationships. Journal of Personality and Social Psychology, 58 (2), 281-291.

[35] Folkman, S., Lazarus, R. S., Gruen, R. J., \& DeLongis, A. (1986). Appraisal, coping, health status, and psychological symptoms. Journal of Personality and Social Psychology, 50(3), 571-579.

[36] Folkman, S., \& Lazarus, R.S. (1988). Coping as a mediator of emotion. Journal of Personality and Social Psychology, 54(3), 466-475.

[37] Fonagy, P. (1994). Mental representations an inter-generational cognitive science perspective. Infant Mental Health, 15, 57-68.
[38] George, C., \& West, M. (1999). Developmental vs. social personality models of adult attachment and mental ill health. British Journal of Medical Psychology, 72, 295-303.

[39] Grau, I. (1999). Skalen zur Erfassung von Bindungsrepra sentationen in Paarbeziehungen. [Scales to assess attachment representations within couples] Zeitschrift fur Differentielle und Diagnostische Psychologie, 20, 142-152.

[40] Hall, S.E., \& Geher, G. (2003). Behavioral and personality characteristicof children with reactive attachment disorder. Journal of Psychology: Interdisciplinary and Applied, 137, 145-162.

[41] Hamarta, E. (2004). Attachment theory. Anadolu University Journal of Education Faculty, 14(1), 53-66.

[42] Hamarta, E., Arslan, C., Saygın, Y., \& Özyeşil, Z. (2009). An Analysis of Coping with Stress Aproaches of University Students with Respect to Their Self Esteem and Irrational Beliefs. Journal of Values Education, 7(18), 25-42.

[43] Hamilton, C. E. (2000). Continuity and discontinuity of attachment from infancy through adolescence. Child Development, 71(3), 690-694.

[44] Hayali-Emir, S. (2014). Investigation of The Relationship Between Coping With Stress Types, Self-Perception And Loneliness Levels With The Attachment Styles Amongst The First Grade University Students. Unpublished master's thesis. University of Karadeniz Teknik, Trabzon.

[45] Hazan, C., \& Shaver, P. (1987). Romantic love conceptualized as an attachment process. Journal of Personality and Social Psychology, 52(3), 511-24.

[46] Hazan, C., \& Shaver, P. R. (1990). Love and work: An attachment-theoretical perspective. Journal of Personality and Social Psychology, (59), 270-280.

[47] Hazan, C., \& Shaver, P. R. (1994). Attachment as an organizational framework for research on close relationship. Psychological Inquiry, 5(1), 1-22.

[48] Huntsinger, E. T. \& Luecken, L. J. (2004). Attachment relationships and health behavior: The mediational role of self-esteem. Psychology and Health, 19, 515-526.

[49] Janssen, C. G. C., Schuengel, C., \& Stolk, J. (2002). Understanding challenging behavior in people with severe and profound intellectual disability: A stress-attachment model. Journal of Intellectual Disability Research, 46(6), 445-453.

[50] Jellema, A. (1999). Cognitive analytic therapy: Developing its theory and practice via attachment theory. Clinical Psychology and Psychotherapy, 6, 16-28.

[51] Kobak, R. R., \& Sceery, A. (1988). Attachment in late adolescence: Working models, affect regulation and representations of self and others. Child Development, 59(1), 135-146.

[52] Korkmaz, M. (1996). Reliability and validity study of a self-esteem scale for adult sample. Unpublished master's thesis. University of Ege, İzmir.

[53] Kulaksızoğlu, A. (1998). Adolescence psychology. İstanbul, Remzi Bookstore.

[54] Kurt, T. (2013). Searching the relation between the resilience, self-esteem, coping and psychological symptoms of divorced parent adolescents: The intermediary role of 
resilience. Unpublished master's thesis. University of Gazi, Ankara.

[55] Lapsey, D., Varshney, N., \& Aalsma, M. (2000). Pathological Attachment and Attachment Style in Late Adolescence. Journal of Adolescence, 23(2) 137-155.

[56] Lazarus, R. S., \& Folkman, S. (1984). Stress, appraisal, and coping. New York, NY: Springer.

[57] Lazarus, R. S. (1993). From psychological stress to the emotions: A history of changing outlooks. Annual Review of Psychology, 44, 1-22.

[58] Lopez F.G., Maurico, A. M., Gormley, B., Simko, T., \& Berger, E. (2001). Adult attachment orientations and college student distress: The mediating role of problem coping style. Journal of Counseling and Development, 79, 459-464.

[59] McCarthy, C. J., Moller, N., \& Fouladi, R. (2001). Continued attachment to parents: Its relationship to affect regulation and perceived stress among college students. Measurement and Evaluation in Counseling and Development, 33, 198-213.

[60] Mikulincer, M. (1998). Adult attachment style and affect regulation: Strategic variations in self-appraisals. Journal of Personality and Social Psychology, 75, 420-435.

[61] Mikulincer, M., \& Florian, V. (1995). Appraisal and coping with a real-life stressful situation: The contribution of attachment styles. Personality and Social Psychology Bulletin, 21, 406-414.

[62] Mikulincer, M., Florian, V., Cowan, P. A., \& Cowan, C. P. (2002). Attachment security in couple relationships: A systemic model and its implications for family dynamics. Family Process, 43, 405-434.

[63] Mikulincer, M., Shaver, P. R., \& Pereg, D. (2003). Attachment theory and affect regulation: the dynamics, development and cognitive consequences of attachment related strategies. Motivation and Emotion, 27(2), 77-102.

[64] Muller, R. T., Lemieux, K. E., \& Sicoli, L. A. (2001). Attachment and psychopathology among formerly maltreated adults. Journal of Family Violence, 16(2), 151-169.

[65] Onur, E. P. (1981). Pre-condition of self-esteem in children. Unpublished master's thesis. University of İstanbul, İstanbul.

[66] Pallant, J. (2005). SPSS survival manual: A Step by step guide to data analysis using SPSS for Windows. Australia: Australian Copyright.

[67] Roberts, J. E., Gotlib, I. H., \& Kassel, J. D. (1996). Adult attachment security and symptoms of depression: the mediating roles of dysfunctional attitudes and low self-esteem. Personality Processes and Individual Differences, 70, 310-320.

[68] Rosenberg, M. (1979). Conceiving the self. New York: Basic Books.

[69] Schneider, E. L., (1991). Attachment theory and research review of the literature. Clinical Social Work, 19(3), 251-266.
[70] Schottenbauer, M. A., Klimes-Dougan, B., Rodriquez, B. F., Arnkoff, D. B., Glass, C. R., \& Lasalle, V. H. (2006). Attachment and affective resolution following a stressful event: General and religious coping as a possible mediators. Mental Health, Religion \& Culture, 9(5), 448-471.

[71] Simpson, J. A. (1990). Influence of attachment styles and romantic relationships. Journal of Personality and Social Psychology, (59), 971-980.

[72] Stahl, S. (2014) Bağlanma korkusu:"evet"de diyemiyorum, "hayır” da. (C. Aydın, Çev.) İstanbul: Kuraldışı Yayınları.

[73] Şahin, N. H., \& Durak, A. (1995). Scale of coping styles with stress: Adaptation for university students. Turkish Journal of Psychology, 10(34), 56-73.

[74] Tabachnick, B. G., \& Fidel, L. S. (2007). Using multivariate statistics. Boston: Pearson Education Inc.

[75] Terzi, S., \& Cankaya, Z. C. (2009). The predictive power of attachment styles on subjective wellbeing and coping with stress of university students. Turkish Psychological Counseling and Guidance Journal, 4(31) 1-11.

[76] Turan, N., \& Tufan, B. (1987). Validity reliability study of Coopersmith Self Esteem Inventory. $23^{\text {rd }}$ National Congress of Psychiatry and Neurological Sciences. İstanbul, 816-817.

[77] Tutar, H. (2011). Crisis and stress management. Ankara: Seçkin Publishing

[78] Trinke, S. J., \& Bartholomew, K. (1997). Hierarchies of attachment relationships in young adulthood. Journal of Social and Personal Relationships, 14(5), 603-625.

[79] Yavuzer, H. (1991). Parent and child. İstanbul, Remzi Bookstore.

[80] Yiğit, R. (2012). Examination of relationship between self-esteem, life satisfaction of riot policemen and their approach to dealing with stress. Journal of Kirşehir Education Faculty, 13(1), 61-75.

[81] Yörükoğlu, A. (1978). Child mental health. Ankara: Türkiye İş Bankası Culture Publications.

[82] Zimmerman, P., \& Becker-Stoll, F. (2002). Stability of attachment representations during adolescence: The influence of ego-identity status. Journal of Adolescence, 25(1), 107-124.

[83] Wei, M., Heppner, P. P., \& Mallinckrodt, B. (2003) Perceived coping as a mediator between attachment and psychological distress: A structural equation modeling approach. Journal of Counseling Psychology, 50, 438-447.

[84] Wei, M., Vogel, D. L., Ku, T. Y., \& Zakalik, R. (2005). Adult attachment, affect regulation, negative mood, and interpersonal problems: Mediating roles of emotional reactivity and emotional cutoff. Journal of Counseling Psychology, 52, 14-24.

[85] Wilkinson, R. B., \& Parry, M. M. (2004). Attachment styles, quality of attachment relationships and components of self-esteem in adolescence. Proceedings of the 39th Australian Psychological Society Annual Conference. 301-305. Melbourne. The Australian Psychological Society, Australia. 